\title{
Effects of Magnesium Deficiency on Mechanisms of Insulin Resistance in Type 2 Diabetes: Focusing on the Processes of Insulin Secretion and Signaling
}

\author{
Krasimir Kostov \\ Department of Pathophysiology, Medical University-Pleven, 1 Kliment Ohridski Str., 5800 Pleven, Bulgaria; \\ dr.krasi_kostov@abv.bg; Tel.: +359-889-257-459
}

Received: 16 February 2019; Accepted: 14 March 2019; Published: 18 March 2019

\begin{abstract}
Magnesium $\left(\mathrm{Mg}^{2+}\right)$ is an essential mineral for human health and plays an important role in the regulation of glucose homeostasis and insulin actions. Despite the widespread clinical evidences for the association of $\mathrm{Mg}^{2+}$ deficiency $(\mathrm{MgD})$ and type 2 diabetes mellitus (T2D), molecular mechanisms by which $\mathrm{Mg}^{2+}$ contributes to insulin resistance (IR) are still under discussion. $\mathrm{Mg}^{2+}$ regulates electrical activity and insulin secretion in pancreatic beta-cells. Intracellular $\mathrm{Mg}^{2+}$ concentrations are critical for the phosphorylation of the insulin receptor and other downstream signal kinases of the target cells. Low $\mathrm{Mg}^{2+}$ levels result in a defective tyrosine kinase activity, post-receptor impairment in insulin action, altered cellular glucose transport, and decreased cellular glucose utilization, which promotes peripheral IR in T2D. MgD triggers chronic systemic inflammation that also potentiates IR. People with T2D may end up in a vicious circle in which MgD increases IR and IR causes $\mathrm{MgD}$, that requires periodic monitoring of serum $\mathrm{Mg}^{2+}$ levels.
\end{abstract}

Keywords: magnesium deficiency; insulin resistance; type 2 diabetes; insulin secretion; insulin signaling

\section{Introduction}

Insulin resistance (IR) is associated with an impaired biological response to insulin stimulation of key target tissues, particularly liver, muscle, and adipose tissue. IR impacts glucose utilization, resulting in a compensatory increase in beta-cell insulin production and hyperinsulinemia [1]. Progression of IR can lead to metabolic syndrome (MetS) and type 2 diabetes mellitus (T2D) [2]. According to the International Diabetes Federation, one in every 11 adults has diabetes and T2D accounts for more than $90 \%$ of these cases [3]. Globally, 500 million adults are expected to have T2D by 2030 [4].

Magnesium $\left(\mathrm{Mg}^{2+}\right)$ is the fourth most common mineral in the human body, after calcium $\left(\mathrm{Ca}^{2+}\right)$, potassium $\left(\mathrm{K}^{+}\right)$, and sodium $(\mathrm{Na}+)$, and the second most abundant intracellular cation after $\mathrm{K}^{+}$[5]. Currently, enzymatic databases list over 600 enzymes for which $\mathrm{Mg}^{2+}$ serves as cofactor and an additional 200 in which $\mathrm{Mg}^{2+}$ may act as activator [6]. Only 1\% of the total $\mathrm{Mg}^{2+}$ in the body is present in extracellular fluids and only $0.3 \%$ is found in the serum [5]. The normal reference range for $\mathrm{Mg}^{2+}$ in the serum is $0.76-1.15 \mathrm{mmol} / \mathrm{L}$. Magnesium deficiency $(\mathrm{MgD})$ is a condition where the serum concentration of $\mathrm{Mg}^{2+}$ in the body is $\leq 0.75 \mathrm{mmol} / \mathrm{L}(1.8 \mathrm{mg} / \mathrm{dL})$ [6]. $\mathrm{Mg}^{2+}$ concentrations $\leq 0.75 \mathrm{mmol} / \mathrm{L}$ may be considered as preclinical hypomagnesemia. Patients are considered frankly hypomagnesemic with serum $\mathrm{Mg}^{2+}$ concentrations $\leq 0.61 \mathrm{mmol} / \mathrm{L}(1.5 \mathrm{mg} / \mathrm{dL})$. MgD can be present without hypomagnesemia. However, hypomagnesemia, when present, is usually indicative of an important systemic $\mathrm{Mg}^{2+}$ deficit [7]. Signs and symptoms of hypomagnesemia usually occur when serum $\mathrm{Mg}^{2+}$ is decreased below $0.5 \mathrm{mmol} / \mathrm{L}(1.2 \mathrm{mg} / \mathrm{dL})$ [7]. A number of factors can negatively 
affect $\mathrm{Mg}^{2+}$ balance in the body and, in the long-term, may result in $\mathrm{MgD}$. Such factors may be a decreased intake of $\mathrm{Mg}^{2+}$ from the food or drinking water [8], an increased $\mathrm{Mg}^{2+}$ loss through the kidneys [9,10], an impaired intestinal absorption of $\mathrm{Mg}^{2+}[11]$, and prolonged use of some medications causing hypomagnesemia [12-14].

$\mathrm{MgD}$ is associated with an increased risk of multiple preclinical and clinical manifestations, including pancreatic beta-cell dysfunction, IR, increased risk of MetS, and T2D [15-17] (Table 1). T2D is often accompanied by alteration of $\mathrm{Mg}^{2+}$ status. Intracellular free $\mathrm{Mg}^{2+}$ levels are reduced in subjects with T2D, when compared with nondiabetic subjects. An increased prevalence of hypomagnesaemia have been identified in patients with T2D, especially in those with poor glycemic control, with a longer duration of the disease, and with the presence of chronic vascular complications [7]. According to various literature sources, $\mathrm{T} 2 \mathrm{D}$ is linked with $\mathrm{MgD}$ at an occurrence rate between $13.5-47.7 \%$ [18].

Table 1. Clinical manifestations of $\mathrm{MgD}$.

\begin{tabular}{l}
\hline General: Anxiety, agitation, irritability, headache, loss of appetite, and nausea. \\
\hline Musculature: Muscle spasm and tetany. \\
\hline CNS/Nerves: Nervousness, migraine, depression, poor memory, low stress tolerance, paraesthesia, tremor, \\
and seizures. \\
\hline $\begin{array}{l}\text { Metabolism: Pancreatic beta-cell dysfunction, IR, decreased glucose tolerance, increased risk of MetS and T2D, } \\
\text { dyslipoproteinemia, disorders of vitamin D metabolism, resistance to PTH, and osteoporosis. }\end{array}$ \\
\hline Cardiovascular system: Arrhythmias, coronary spasm, atherosclerosis, hypertension, arterial stiffness, \\
endothelial dysfunction, and increased platelet aggregation. \\
\hline Electrolytes: Sodium retention, hypokalemia, and hypocalcemia. \\
\hline
\end{tabular}

\section{Effects of MgD on Molecular Mechanisms of Insulin Action}

Despite the widespread clinical evidence for the association of $\mathrm{MgD}$ and $\mathrm{T} 2 \mathrm{D}$, molecular mechanisms by which $\mathrm{Mg}^{2+}$ contributes to IR are still under discussion. Currently, the strongest line of evidence supports the effects of $\mathrm{MgD}$ on insulin secretion, insulin sensitivity, systemic inflammatory response, and the activity of certain key $\mathrm{Mg}^{2+}$-dependent enzymes of carbohydrate and energy metabolism.

\subsection{Effects of $M g D$ on Insulin Secretion}

The insulin producing beta cells are electrically excitable and use changes in membrane potential to couple variations in blood glucose to changes in insulin secretion. After entering the pancreatic beta cells via GLUT2, glucose is converted to glucose-6-phosphate (G6P) by glucokinase (GK). The product of this enzymatic reaction, G6P, is further processed to produce ATP [19]. Subsequent increases in the cytosolic adenosine triphosphate (ATP) / adenosine diphosphate (ADP) ratio control cell membrane potential by inhibiting ATP-sensitive $\mathrm{K}^{+}$(KATP) channels, eliciting a membrane depolarization [20]. An important physiological consequence of the KATP channel closure and the depolarization of the beta-cell membrane is the influx of $\mathrm{Ca}^{2+}$ through the L-type $\mathrm{Ca}^{2+}$ channels, and insulin release [19] (Figure 1). This occurs when the membrane potential reaches approximately $-50 \mathrm{mV}$ [20]. Then, the increase in cytosolic $\mathrm{Ca}^{2+}$ is rapidly reversed by very active $\mathrm{Ca}^{2+}$ pumps, such as the sarco/endoplasmic reticulum $\mathrm{Ca}^{2+}$-ATPase [20]. Secretion of insulin in response to increases in blood glucose levels occurs in two phases [21]. The first phase is rapid and occurs within the few minutes. This phase is followed by a second phase of insulin release, which is more prolonged. Observations show that the first phase of insulin secretion is lost in patients with T2D [22]. 


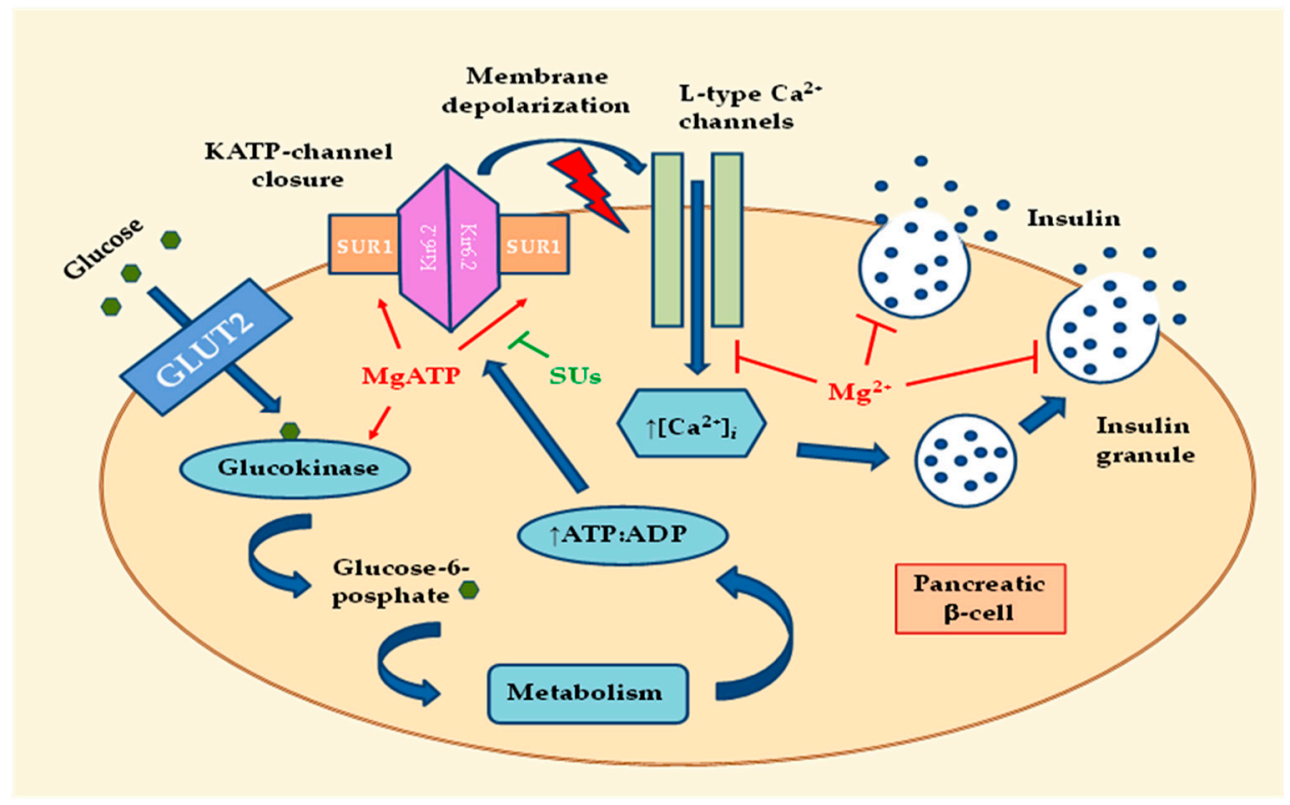

Figure 1. Regulatory role of $\mathrm{Mg}^{2+}$ in the insulin secretion from pancreatic beta cells. The normal intracellular $\mathrm{Mg}^{2+}$ concentrations are of utmost importance for the optimal insulin secretion. The first step of beta-cell glucose metabolism is the conversion of glucose to glucose-6-phosphate by glucokinase, which subsequently results in a rise in intracellular ATP. MgD can directly influence the rate of GK activity because the enzyme's action depends on MgATP. Closure of the KATP channel depends on the binding of ATP to the Kir6.2 subunits. Opening of the KATP channel depends on the binding of MgATP to the SUR1 subunits. An important consequence of the closure of KATP channels is the depolarization of the beta-cell membrane, which stimulates $\mathrm{Ca}^{2+}$ influx through L-type $\mathrm{Ca}^{2+}$ channels and insulin release. In MgD, intracellular levels of ATP and MgATP decrease. This disturbs the coupling between the chemical signal (blood glucose) and the electrical stimulation of the beta cells, resulting in a disturbance of the normal phases of insulin release. SUs antagonize the binding of MgATP to the SUR1, which induces channel closure and potentiates insulin secretion. Legend: GLUT2, glucose transporter type 2; KATP, ATP-sensitive $\mathrm{K}^{+}$channel; SUR1, sulfonylurea receptor 1 subunit of KATP; Kir6.2, inwardly rectifying $\mathrm{K}^{+}$channel subunit of KATP; SUs, sulfonylurea drugs; $\mathrm{Mg}^{2+}$, magnesium; $\mathrm{MgATP}, \mathrm{Mg}^{2+}$-ATP complex; $\uparrow\left[\mathrm{Ca}^{2+}\right] i$, increased intracellular $\mathrm{Ca}^{2+}$ concentrations; $\uparrow$ ATP:ADP, increased ATP/ADP ratio.

The tandem GLUT2 and GK is often referred to as a glucose-sensor controlling blood sugar levels. Mutations that alter the glucose-dependent activity of GK effectively adjust the set point for whole-body glucose homeostasis [20]. $\mathrm{Mg}^{2+}$ can directly influence the rate of GK activity by acting as a cofactor for adenine nucleotides (MgATP) [19]. The KATP channel plays a key role in insulin release from pancreatic beta cells. The KATP channel consists of four central inwardly rectifying $\mathrm{K}^{+}$ channel (Kir6.2) subunits, surrounded by four regulatory sulfonylurea receptor 1 (SUR1) subunits, whose activity is controlled by the intracellular ATP/ADP ratio [19]. Activating mutations in Kir6.2 or SUR1 subunits of the channel may impair ATP binding at Kir6.2 or may enhance MgADP activation at SUR1. This may disrupt the functioning of KATP channels. Disturbances of this regulation can lead to diabetes in young adults or increase the risk of T2D. These mutations suggest the important role of ATP and MgATP in the regulation of KATP channels [23]. Closure of the KATP channel depends on the binding of ATP to the Kir6.2 subunits. Opening of the KATP channel depends on the binding of MgATP to the SUR1 subunits [19]. The therapeutic target of sulfonylurea drugs (SUs) is the changing of this balance by antagonizing the MgATP binding to the SUR1, which inhibits opening and induces channel closure [23]. In MgD, intracellular levels of ATP and MgATP decrease, which inhibits the closure and opening of KATP channels. This disturbs the coupling between the chemical signal (blood glucose) and the electrical stimulation of the beta-cells, resulting in a disturbance of the normal phases 
of insulin release. MgD may impair the functioning of the GK, G6P formation, and the accumulation of ATP in beta cells, which may impair closure of the KATP channels. This delays early and late plasma insulin responses to glucose. At physiological extracellular concentrations of $\mathrm{Mg}^{2+}$, intracellular levels of MgATP are sufficient for the normal opening of the KATP channels. In MgD, intracellular levels of MgATP decrease, which inhibits the opening of KATP channels. This induces a longer depolarization of the beta-cell plasma membrane followed by the release of more insulin (Figure 1). This effect of extracellular $\mathrm{Mg}^{2+}$ on insulin secretion was found in healthy human subjects. In subjects with $0.79 \mathrm{mmol} / \mathrm{L}$ plasma $\mathrm{Mg}^{2+}$, fasting plasma insulin was $23 \mu \mathrm{U} / \mathrm{mL}$, while in those with plasma $\mathrm{Mg}^{2+}$ 0.87 or $1.00 \mathrm{mmol} / \mathrm{L}$, fasting plasma insulin amounted to $11 \mu \mathrm{U} / \mathrm{mL}$ [24]. From the above, it can be concluded that $\mathrm{MgD}$ can disrupt the normal functioning of beta cells and, thus, may trigger beta-cell dysfunction in T2D.

\subsection{Effects of $M g D$ on Peripheral Insulin Sensitivity}

Insulin action begins with the binding of insulin to the insulin receptor (INSR) on the cell membrane of the target cells. The INSR belongs to the family of tyrosine kinase (TK) receptors [25]. INSR is an integral membrane glycoprotein, which is formed by two alpha and two beta subunits. [26]. In the insulin signaling process, insulin binds to the alpha subunit of the receptor that activates the TK in beta subunit. This process also starts autophosphorylation of several tyrosine (Tyr) residues present in the beta subunit. Autophosphorylated residues are then recognized by phosphotyrosine-binding domains of different adaptor proteins belonging to the INSR substrate family (IRS) members (IRS-1 to -6) [27]. The IRS proteins do not contain any intrinsic kinase activity but organize signaling complexes and initiate intracellular signaling pathways [28].

Most insulin actions are carried out by activation of two main signaling pathways, as follows: (1) The Ras/mitogen-activated protein kinases pathway (Ras/MAPK), which regulates gene expression and insulin-associated mitogenic effects, and (2) the phosphatidylinositol-3-kinase (PI3K)/ Akt (protein kinase B) pathway, responsible for most its metabolic actions. The PI3K/Akt kinase pathway plays a central role in insulin signaling, since its activation leads to phosphorylation of an important number of substrates with key functions in a wide variety of biological processes, including glucose transport stimulation, glycogen and protein synthesis, and lipogenesis. Akt appears to play an important role in insulin metabolic actions, including muscle and adipose tissue glucose uptake through glucose transporter type 4 (GLUT4) translocation from intracellular compartments to the cell membrane. Additionally, Akt participates in the regulation of glycogen synthesis by glycogen synthase kinase 3 inhibition [26] (Figure 2).

Most common IR alterations include a decrease in the number of INSRs and of their catalytic activity, an increased serine (Ser)/ threonine (Thr) phosphorylation of INSR, an increased Ser/Thr phosphorylation and degradation of IRS proteins, an increase in Tyr phosphatase activity, a decrease in PI3K and Akt kinases activity, and defects in GLUT4 expression and function. These alterations reduce glucose uptake in muscular and adipose tissues and promote alterations at the metabolic level [26,29]. A number of clinical and experimental data indicate that $\mathrm{MgD}$ may be associated with a large part of these alterations. 


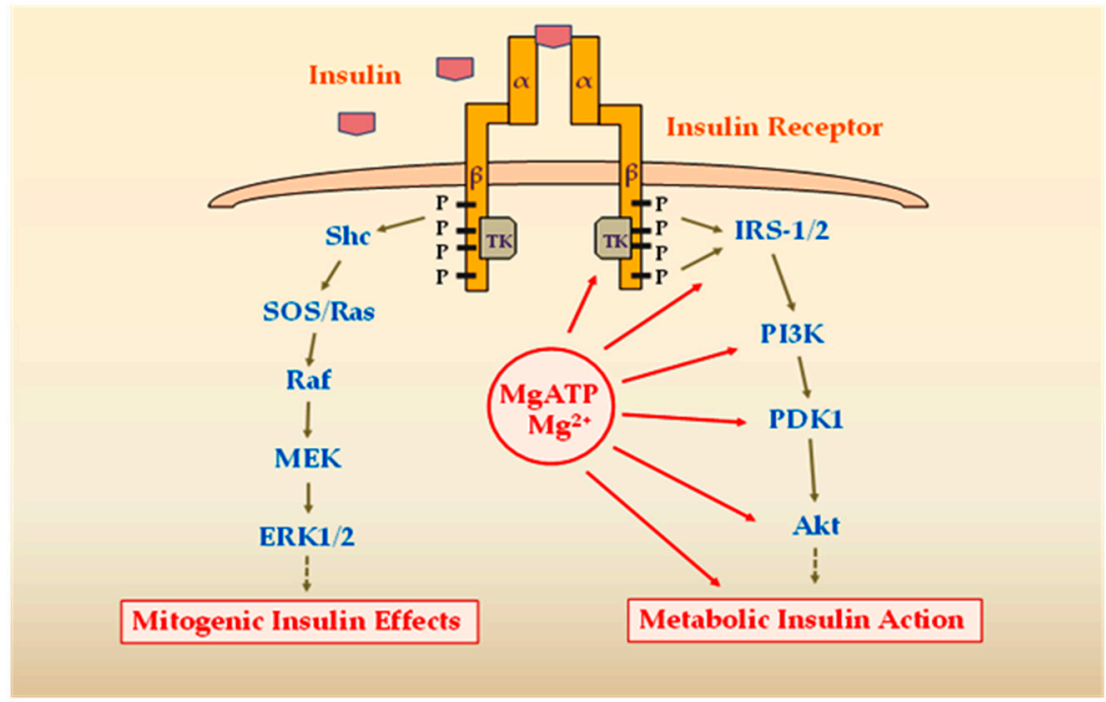

Figure 2. Schematic diagram showing the two major insulin signaling pathways and the role of $\mathrm{Mg}^{2+}$ in metabolic signaling. The Ras/MAPK pathway regulates gene expression and insulin-associated mitogenic effects. The PI3K/Akt kinase pathway regulates the metabolic actions of insulin, which include glucose uptake by GLUT4 mobilization, glycogen and protein synthesis, and lipogenesis. Intracellular $\mathrm{Mg}^{2+}$ concentrations are critical for the phosphorylation of INSR and the activity of other signal kinases, where $\mathrm{Mg}^{2+}$ operates together with ATP as a kinase substrate. $\mathrm{Mg}^{2+}$ may exert regulatory influence on TK of INSR and other enzymes, mediating the metabolic effects of insulin. Legend: TK, tyrosine kinase; IRS, insulin receptor substrate; PI3K, phosphatidylinositol-4,5-bisphosphate-3-kinase; PDK1, 3-phosphoinositide dependent protein kinase-1; Akt, protein kinase B; Shc, SH2 domain-containing protein; SOS, son of sevenless; MEK, mitogen-activated extracellular signal-regulated kinase; ERK1/2, extracellular signal-regulated kinase 1/2; $\mathrm{MgATP}, \mathrm{Mg}^{2+}$-ATP complex; $\mathrm{Mg}^{2+}$, magnesium.

\subsubsection{Effects of MgD-Induced Hyperinsulinemia on Downstream Insulin Signaling}

In $\mathrm{MgD}$, intracellular levels of $\mathrm{Mg}^{2+}$, ATP, and especially of MgATP decrease, as a result of which SUR1 channel subunit cannot be adequately activated. This ultimately leads to an increase in the basal secretion of insulin $[19,23]$ (Figure 3). Basal hyperinsulinemia perpetuates IR by a wide range of mechanisms [30]. These mechanisms are related to the functioning of the INSR and the IRS proteins, which are targets for negative feedback control [31]. Continuous exposure to elevated levels of insulin causes a reduction in the number of receptors exposed on the cell surface by promoting internalization as well as degradation of hormone-occupied receptors. Under conditions of hyperinsulinemia, the receptor's kinase activity is diminished, probably because of combined effects of phosphorylation of Ser residues on the receptor, dephosphorylation of Tyr residues by the action of phosphatases, and the binding of inhibitory molecules. The IRS proteins also become phosphorylated on Ser and Thr residues, which reduces downstream signaling [30]. 


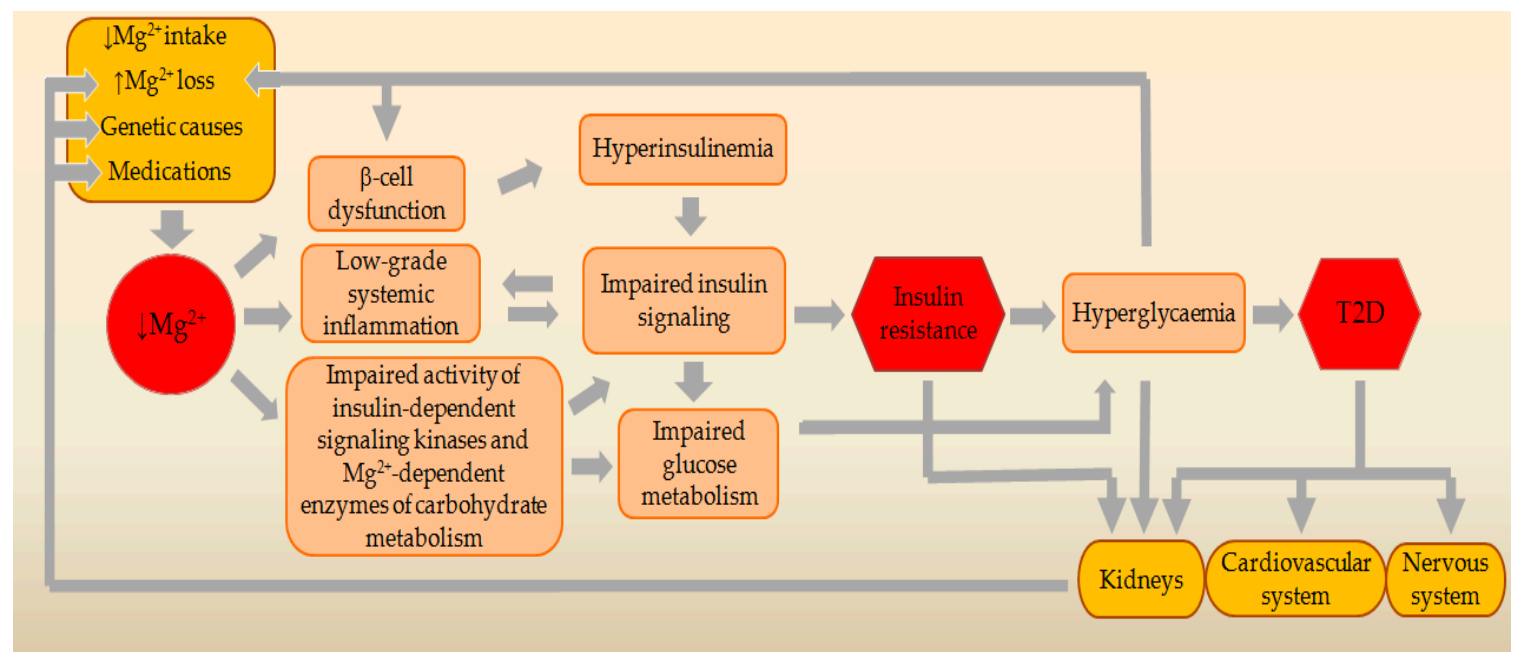

Figure 3. Schematic presentation of the pathogenetic vicious circle between MgD and IR in T2D. A number of factors can negatively affect $\mathrm{Mg}^{2+}$ balance in the body and may result in $\mathrm{MgD}$. MgD may cause beta-cell dysfunction, impaired insulin signaling, development of chronic systemic inflammation, and change in activity of key $\mathrm{Mg}^{2+}$-dependent signaling kinases and enzymes of carbohydrate and energy metabolism. This can ultimately contribute to development of IR and T2D. Legend: $\downarrow \mathrm{Mg}^{2+}$, magnesium deficiency; T2D, type 2 diabetes mellitus.

\subsubsection{Effects of $\mathrm{MgD}$ on Activity of the Insulin-Signaling Kinases}

Activation of the INSR initiates a cascade of phosphorylation events. The conformational changes and autophosphorylation of the receptor occur at the time of insulin binding, resulting in phosphorylation of receptor substrates such as IRS and Shc proteins. Shc activates the Ras-MAPK pathway, whereas the IRS proteins mostly activate the PI3K-Akt pathway. Activated PI3K leads to the generation of the second messenger phosphatidylinositol-3,4,5-triphosphate (PIP3). Membrane-bound PIP3 activates 3-phosphoinositide dependent protein kinase-1 (PDK1), which phosphorylates and activates Akt and atypical protein kinases. Akt mediates most of insulin's metabolic effects, regulating glucose transport, lipid synthesis, gluconeogenesis, and glycogen synthesis [32]. Since $\mathrm{Mg}^{2+}$ is a necessary cofactor in all ATP transfer reactions, intracellular $\mathrm{Mg}^{2+}$ concentrations are critical for the phosphorylation of the INSR and other downstream signal kinases of the target cells [33]. $\mathrm{Mg}^{2+}$ participates in a number of reactions related to kinase activation, where it operates together with ATP as a kinase substrate. Additionally, $\mathrm{Mg}^{2+}$ has the ability to connect to the regulatory site of the INSR tyrosine kinase (IRTK) and thus can exert regulatory influence. The affinity of IRTK for MgATP increases when the concentration of free $\mathrm{Mg}^{2+}$ increases and the IRTK affinity for free $\mathrm{Mg}^{2+}$ increases when the MgATP concentration increases [16] (Figure 2). These data suggest that the impairment of kinase activity in MgD may lead to insulin signaling defects and IR (Figure 3).

\subsection{Effects of $M g D$ on Low-Grade Systemic Inflammation}

The inflammatory environment is regarded as an important contributor to IR. Inflammation plays an important role in the development of IR through various cytokines and molecular pathways. Therefore, both the fluctuation of cytokines and the status of relevant signaling pathways should be considered in the analysis of inflammation-associated IR [34]. MgD significantly increases production of various proinflammatory molecules, such as interleukin (IL)-1 $\beta$ (IL-1 $\beta$ ), IL-6, tumor necrosis factor- $\alpha$ (TNF- $\alpha$ ), vascular cell adhesion molecule-1, and plasminogen activator inhibitor-1, and decreases expression and activity of the antioxidant enzymes such as glutathione peroxidase, superoxide dismutase, and catalase (Figure 3). Cellular and tissue levels of important antioxidants such as glutathione, vitamin C, vitamin E, and selenium are also reduced [35]. IL-1 $\beta$ is a master cytokine that regulates the expression of various other pro-inflammatory cytokines, adipokines, and chemokines. It 
can induce an inflammatory response and can reduce the expression of IRS- 1 at the ERK-dependent transcriptional level and ERK-independent post-transcriptional level. Production of IL- $1 \beta$ is mainly regulated by diet-induced metabolic stress [36]. IL-6 is secreted by multiple tissues, particularly adipose tissue, and is recognized as an inflammatory mediator that causes IR by reducing the expression of IRS-1 and GLUT4. IL-6 also induces IR by blocking the PI3K pathway. Production of IL- 6 is regulated by IL- $1 \beta[34,36]$. Recently, it has been found that serum level of TNF- $\alpha$ is positively correlated with the pathophysiology of IR which exhibits that TNF- $\alpha$ is also a main causative factor that contributes to the development of IR [36]. TNF- $\alpha$ stimulates genes for IL- $1 \alpha$, IL-1 $\beta$, IL-6, IL-8, IL-18, and cycloxygenase-2 [37]. TNF- $\alpha$ can trigger various transcriptional pathways such as nuclear factor kappa B (NF- $\mathrm{kB}$ ) and c-Jun NH2-terminal kinases (JNK). Once NF- $\kappa B$ and JNK are activated, they phosphorylate Ser307 in IRS-1 and this may result in impairment of INSR-mediated Tyr phosphorylation of IRS-1 [36]. In addition, TNF- $\alpha$ may reduce protein levels of GLUT4, along with a decreased activity of Akt in adipocytes [38]. Chemokines are an important class of pro-inflammatory mediators. Their production is dependent on the activation IL-1 $\beta$ and various transcriptional pathways. Overexpression of monocyte chemotactic protein-1 (MCP-1) in adipose tissues was observed to be responsible for the increase in adipose tissue macrophages and induction of IR [36].

The results of several clinical studies have shown that increased synthesis and release of proinflammatory cytokines may be the link between obesity and MetS. On the other hand, hypomagnesemia triggers low-grade chronic inflammation and $\mathrm{Mg}^{2+}$ deficit may be associated with the development of MetS [39]. Guerrero-Romero et al. found a link between $\mathrm{Mg}^{2+}$ levels, inflammation, and oxidative stress, as risk factors for the development of MetS [15]. These findings support the hypothesis that $\mathrm{MgD}$ can play an important role in the pathophysiology of MetS and the actuation of the inflammatory reaction caused by the shortage of $\mathrm{Mg}^{2+}$ could be the link between $\mathrm{MgD}$ and MetS [39]. There is a strong correlation between mass of adipose tissue and development of IR in T2D. Corica et al. have recently shown that patients with T2D, having abdominal obesity, a lipid profile with high risk, and high blood pressure, have lower levels of $\mathrm{Mg}^{2+}$, compared with patients without metabolic risk factors. Furthermore, plasma triglycerides and waist circumference were independently associated with hypomagnesaemia [15]. An important role in obesity is the endocrinological function of adipocytes. Various effectors such as leptin, adiponectin, IL-1, IL-6, IL-8, IL-18, TNF- $\alpha$, resistin, ghrelin, visfatin, orexin, adipsin, and cortisol are produced by adipocytes or are related to obesity [16]. The most important adipose derived mediators that cause IR are free fatty acids (FFAs) and adipokines. Recent evidence has suggested that saturated FFAs may act through binding to toll-like receptor 4 . This binding leads to the activation of NF- $\mathrm{KB}$ and activator protein- 1 transcription factors and these lead to an increased production of proinflammatory cytokines, such as TNF- $\alpha$, IL-6, and IL-1 in adipose tissue [38]. Adipokines are a large group of pro-inflammatory mediators that include leptin, TNF- $\alpha$, IL-6, and MCP-1. Adiponectin is the only adipokine that has anti-inflammatory action. The level of adiponectin is downregulated in obesity and correlates positively with insulin sensitivity. The imbalance between leptin and adiponectin may be an important cause for the development of IR [36].

$\mathrm{MgD}$ is often found in people with MetS and T2D, which are connected with higher plasma concentrations of C-reactive protein (CRP) [40]. Low $\mathrm{Mg}^{2+}$ intake is associated with a higher probability of increased serum CRP levels in children [41]. There is also an association between the dietary intake of $\mathrm{Mg}^{2+}$ and elevated CRP levels in the adult population [42]. Intake of $\mathrm{Mg}^{2+}$ is also inversely related to the level of high-sensitivity CRP, IL-6, and fibrinogen [43]. CRP is an acute-phase protein synthesized by the liver. It is an inflammatory marker whose expression is increased significantly during inflammation, mainly due to its regulation by proinflammatory cytokines such as IL- 6 and TNF- $\alpha$. Elevated CRP levels may be a potential risk factor or marker for vascular complications in T2D. However, there is no clear causality between serum CRP, IR, and T2D, which suggests that CRP is more likely to be a downstream marker that links inflammation to IR [34]. 
Another inflammatory mediator that has been recently implicated in the pathogenesis of several chronic diseases, including MetS and T2D, is the lipid mediator leukotriene B4 (LTB4). LTB4 promotes IR in adipose tissue directly and by enhances the production of other proinflammatory cytokines [44].

\subsection{Effects of $\mathrm{MgD}$ on Key $\mathrm{Mg}^{2+}$-Dependent Enzymes of Carbohydrate and Energy Metabolism}

$\mathrm{MgD}$ can also be a rate-limiting factor in carbohydrate and energy metabolism, since many of the enzymes in these processes require $\mathrm{Mg}^{2+}$ or MgATP as a cofactor during reactions that use the phosphorus bond (Figure 3) [45]. In pancreatic beta cells $\mathrm{Mg}^{2+}$ can directly influence GK activity because the enzyme's action depends on MgATP [19]. In the liver, $\mathrm{Mg}^{2+}$ is an important regulator of enzymes in gluconeogenesis. Phosphoenolpyruvate carboxy kinase (PEPCK), fructose-1,6-bisphosphatase (F1,6BP), pyruvate carboxylase (PC), and glucose-6-phosphatase are rate limiting enzymes in this process. Of these four enzymes, $\mathrm{Mg}^{2+}$ is required by three, those are PC, PEPCK, and F1,6BP [46]. Glycogen synthase kinase 3 (GSK3) is a key enzyme that regulates glycogen synthase (GS). Insulin signaling was the first pathway found to increase the inhibitory serine phosphorylation of GSK3 by activation of PI3K and Akt [47]. GSK3 is a constitutively active enzyme and hormones and substances that mediate signaling through GSK3 pathways typically trigger a reduction in kinase activity. The insulin signal transduction pathway provides a clear example of this. GSK3 phosphorylates GS at a cluster of residues (Ser641, Ser645, and Ser649) to maintain it in a dormant state. Insulin causes GSK3 to become phosphorylated at Ser21 of GSK3 $\alpha$ and at the homologous position, Ser9, in GSK3 $\beta$. These are inhibitory post-translational modifications that diminish the kinase activity of GSK3, so insulin signaling relieves GSK3-mediated suppression of GS activity and results in the synthesis of glycogen [48]. $\mathrm{Mg}^{2+}$ divalent cations are ligands with GSK3 functioning to balance the negative charge that is on the aspartic acid side chains. Asp200 and Asp264 both have side chains with net negative charges and $\mathrm{Mg}^{2+}$ cations can neutralize their negative charge. This process can be inhibited by lithium $\left(\mathrm{Li}^{+}\right)$because its cations directly compete with the $\mathrm{Mg}^{2+}$ cations. $\mathrm{Li}^{+}$is a mood stabilizer, widely used in the chronic treatment of bipolar disorders. $\mathrm{Li}^{+}$ ions directly inhibit GSK-3 by interrupting the ligand complex with $\mathrm{Mg}^{2+}$ [49]. $\mathrm{Mg}^{2+}$ is an important controller of glycolysis and the Krebs cycle. $\mathrm{Mg}^{2+}$ regulates important glycolytic enzymes, such as hexokinase, phosphofructokinase, phosphoglycerate kinase, and pyruvate kinase. The most important effect is attributable to the MgATP complex, which is a cofactor for these enzymes [50,51]. $\mathrm{Mg}^{2+}$ has been documented to enhance the activity of three important mitochondrial dehydrogenases involved in energy metabolism. The activities of isocitrate dehydrogenase and 2-oxoglutarate dehydrogenase complex (OGDH) are stimulated directly by the $\mathrm{Mg}^{2+}$-isocitrate complex and free $\mathrm{Mg}^{2+}$, respectively. The activity of pyruvate dehydrogenase complex is stimulated indirectly via the stimulatory effect of $\mathrm{Mg}^{2+}$ on pyruvate dehydrogenase phosphatase, which dephosphorylates and, thus, activates the pyruvate decarboxylase. The results indicate that OGDH is the main step of oxidative phosphorylation modulated by $\mathrm{Mg}^{2+}$ when 2-oxoglutarate is the oxidisable substrate. $\mathrm{Mg}^{2+}$ is also an activator of ATP synthesis by mitochondrial F0/F1-ATPase [50].

\section{Genetic Relationships between MgD and T2D}

Intracellular $\mathrm{Mg}^{2+}$ concentrations are determined by various $\mathrm{Mg}^{2+}$ channels and transporters. Of these, transient receptor potential melastatin type 6 and 7 (TRPM6 and TRPM7) ion channels, solute carrier family 41 member 1 (SLC41A1), and $\mathrm{Mg}^{2+}$ transporter 1 (MagT1) play a major role. Several groups of researchers have investigated the association between genetic variations in these $\mathrm{Mg}^{2+}$ transporters and risk for T2D. Until now, single nucleotide polymorphisms have been found in the TRPM6 and SLC41A1 genes, which are associated with an increased risk for T2D [19]. Patients with dominant mutations in the hepatocyte nuclear factor 1B (HNF1B) gene or recessive mutations in the pterin-4 alpha-carbinolamine dehydratase 1 (PCBD1) gene can develop hypomagnesemia and maturity-onset diabetes of the young $[9,52,53]$. Also, the genetic changes of the pancreatic beta-cell KATP channels can play a central role in the change of insulin secretion. Common variants in the potassium inwardly rectifying channel, subfamily J, member 11 (KCNJ11) and ATP-binding cassette, 
sub-family C, member 8 (ABCC8) genes, that encode channel subunits Kir6.2 and SUR1, were identified as T2D susceptibility loci. KATP channel activity is regulated by the intracellular balance of MgATP and MgADP and depends on the presence of $\mathrm{Mg}^{2+}$ ions. Low $\mathrm{Mg}^{2+}$ intake and imbalance in intracellular $\mathrm{Mg}^{2+}$ concentrations may interact with KATP ion channel variants in affecting T2D risk [54] (Figure 3).

\section{Main Causes and Risk Factors for MgD}

A number of factors can negatively affect $\mathrm{Mg}^{2+}$ balance in the body and, in the long-term, may result in $\mathrm{MgD}$. Such factors may be a decreased intake of $\mathrm{Mg}^{2+}$ from the food or drinking water, an increased $\mathrm{Mg}^{2+}$ loss through the kidneys, an impaired intestinal absorption of $\mathrm{Mg}^{2+}$, and the use of some medications (Figure 3).

\subsection{Decreased Intake of $\mathrm{Mg}^{2+}$ from the Food or Drinking Water}

Recommended Dietary Allowance (RDA) for $\mathrm{Mg}^{2+}$ is $420 \mathrm{mg}$ /day for men and $320 \mathrm{mg} /$ day for women [55]. In the Western world, dietary intake of $\mathrm{Mg}^{2+}$ is subnormal, with shortfalls of between 65 and $225 \mathrm{mg}$ of $\mathrm{Mg}^{2+}$ /day, depending upon geographic region [56]. Dietary studies in Europe and the United States of America (USA) show that people who consume Western-style diets have low $\mathrm{Mg}^{2+}$ content, $<30-50 \%$ of the RDA for $\mathrm{Mg}^{2+}$. It is assumed that the $\mathrm{Mg}^{2+}$ intake in the USA has decreased over the past 100 years, from about $500 \mathrm{mg} /$ day to $175-225 \mathrm{mg} /$ day [57]. Dietary intake of $\mathrm{Mg}^{2+}$ has also been shown to be insufficient in the general United Kingdom population [58] and in middle-aged French adults [59]. This is probably the result of the increasing use of processed foods [57]. Refining or processing of food may deplete $\mathrm{Mg}^{2+}$ content by nearly $85 \%$. Furthermore, the incidence rate of $\mathrm{MgD}$ can vary considerably in different regions due to the large differences of $\mathrm{Mg}^{2+}$ content in drinking water, which can provide up to $30 \%$ of daily needs [60]. Water is a variable source of $\mathrm{Mg}^{2+}$ intake. Since this varies depending on the area from which water comes, $\mathrm{Mg}^{2+}$ intake from water is usually not estimated to a sufficient extent [61]. In drinking water, the levels of $\mathrm{Mg}^{2+}$ should be at least $10 \mathrm{mg} / \mathrm{L}$ and ideally 25-100 mg/L [62]. Therefore, it seems reasonable to assume that $\mathrm{MgD}$ is mainly related to the low intake of $\mathrm{Mg}^{2+}$ in food and drinking water, which may lead to a negative balance over time [60]. Inadequate dietary intake of $\mathrm{Mg}^{2+}$ is an independent risk factor for the development of T2D. Lopez-Ridaura et al., evaluating 37,309 participants free of cardiovascular disease and T2D, found a significant inverse association between $\mathrm{Mg}^{2+}$ intake and diabetes risk [63]. Van Dam et al. reported a similar relationship. Their findings indicated that a diet high in $\mathrm{Mg}^{2+}$-rich foods, particularly whole grains, is associated with a substantially lower risk of T2D [64].

\subsection{Increased Loss of $\mathrm{Mg}^{2+}$ through the Kidneys}

$\mathrm{Mg}^{2+}$ homeostasis is governed by reabsorption of $\mathrm{Mg}^{2+}$ from primary urine in the kidney. Of about $2,400 \mathrm{mg} \mathrm{Mg}^{2+}$ that is ultra-filtrated daily, $95-99 \%$ is reabsorbed by the nephrons. The causes of $\mathrm{Mg}^{2+}$ loss through the kidneys are elucidated in detail during the recent years and may involve various damage of the transport systems located in the thick ascending limb (TAL) of Henle's loop and distal convoluted tubules [6,12]. Inherited tubular disorders that result in urinary $\mathrm{Mg}^{2+}$ waste are Gitelman syndrome, Bartter syndrome, familial hypomagnesemia with hypercalciuria and nephrocalcinosis (FHHNC), autosomal-dominant hypocalcemia with hypercalciuria (ADHH), isolated dominant hypomagnesemia (IDH) with hypocalciuria, isolated recessive hypomagnesemia (IRH) with normocalcemia, and hypomagnesemia with secondary hypocalcemia (HSH) $[9,65,66]$. Recent findings in obese diabetic rats found that TRPM6 was down regulated, explaining renal $\mathrm{Mg}^{2+}$ waste. $\mathrm{Mg}^{2+}$ uptake in the TAL of Henle may also have a role, since hyperinsulinemia and IR may lead to a decreased $\mathrm{Mg}^{2+}$ uptake and an increase $\mathrm{Mg}^{2+}$ excretion. Hyperglycemia also leads to increased urinary $\mathrm{Mg}^{2+}$ waste, contributing to $\mathrm{Mg}^{2+}$ depletion. Plasma $\mathrm{Mg}^{2+}$ levels were found inversely correlated with the urinary $\mathrm{Mg}^{2+}$ excretion rate and with fasting blood glucose values, suggesting that the tubular reabsorption of $\mathrm{Mg}^{2+}$ is decreased in the presence of severe hyperglycemia [67]. Several drugs, such as loop diuretics (including furosemide, bumetanide, and ethacrynic acid), produce large increases in $\mathrm{Mg}^{2+}$ excretion through the inhibition of the electrical gradient necessary for $\mathrm{Mg}^{2+}$ reabsorption in the TAL. Long-term thiazide 
diuretic therapy also may cause $\mathrm{MgD}$, through enhanced $\mathrm{Mg}^{2+}$ excretion and, specifically, reduced renal expression levels of the epithelial $\mathrm{Mg}^{2+}$ channel TRPM6. Many nephrotoxic drugs, including cisplatin, cyclosporine, and tacrolimus, can produce urinary $\mathrm{Mg}^{2+}$ waste by a variety of mechanisms, some of which are still unknown [12].

\subsection{Impaired Intestinal Absorption of $\mathrm{Mg}^{2+}$}

Intestinal $\mathrm{Mg}^{2+}$ absorption occurs predominantly in the small intestine via a paracellular pathway and smaller amounts are absorbed into the colon, mainly via a transcellular pathway. Paracellular $\mathrm{Mg}^{2+}$ absorption occurs through simple diffusion and involves the transport of $\mathrm{Mg}^{2+}$ through small spaces between epithelial cells and depends on specialized transmembrane proteins, claudins, which control ion permeability. The transcellular pathway of $\mathrm{Mg}^{2+}$ absorption depends on the TRPM6 and TRPM7 transporters. Various factors influence the intestinal uptake of $\mathrm{Mg}^{2+}$ and are of substantial importance for the supply of this mineral [68]. Impaired gastrointestinal $\mathrm{Mg}^{2+}$ absorption is a common underlying basis for hypomagnesemia, especially when the small bowel is involved, due to disorders associated with malabsorption, chronic diarrhea, or steatorrhea, or as a result of bypass surgery on the small intestine. As there is some $\mathrm{Mg}^{2+}$ absorption in the colon, patients with ileostomies can develop hypomagnesemia [69]. $\mathrm{Mg}^{2+}$ absorption may be impaired in a number of diseases, e.g., Crohn's disease, ulcerative colitis, coeliac disease, short bowel syndrome, and Whipple's disease [11,57]. Genetic modification of the TRPM6 channel was identified as the underlying cause for the autosomal recessive disorder HSH. Individuals with $\mathrm{HSH}$ fail to effectively absorb $\mathrm{Mg}^{2+}$ when the intraluminal intestinal concentration of $\mathrm{Mg}^{2+}$ is low [70]. Proton pump inhibitors (PPIs) are commonly used medicines, to reduce gastric acid secretion, that can affect the gastrointestinal absorption of $\mathrm{Mg}^{2+}$. Hypomagnesemia is a recognized side-effect of PPIs [13]. Use of metformin to treat T2D may also cause hypomagnesaemia due to gastrointestinal losses, such as the risk increases with the duration of the therapy [14]. This may be an important cause of the higher incidence of $\mathrm{MgD}$ among the $\mathrm{T} 2 \mathrm{D}$ population.

\section{5. $\mathrm{Mg}^{2+}$ Supplementation and Dietary Approaches for Improving Insulin Sensitivity in T2D}

Benefits of $\mathrm{Mg}^{2+}$ supplementation in diabetic subjects have been found in a number of clinical studies. They demonstrate that oral administration of $\mathrm{Mg}^{2+}$ reduces IR and improves insulin sensitivity in T2D patients, as well as in overweight nondiabetic subjects (Table 2).

Table 2. The benefits of $\mathrm{Mg}^{2+}$ supplementation for improvement of insulin sensitivity in patients with T2D and overweight non-diabetic subjects.

\begin{tabular}{|c|c|c|}
\hline Study & $\mathrm{Mg}^{2+}$ Intake (mg/day) & Results \\
\hline Rodrguez-Moran et al., 2003 [71] & $\begin{array}{l}50 \mathrm{~mL} \mathrm{MgCl}{ }_{2} \text { solution ( } 50 \mathrm{~g} \mathrm{MgCl}_{2} \text { per } \\
1000 \mathrm{~mL} \text { solution) daily for } 16 \text { weeks. }\end{array}$ & $\begin{array}{l}\text { Oral supplementation with } \mathrm{MgCl}_{2} \text { solution restores } \\
\text { serum } \mathrm{Mg}^{2+} \text { levels, improving insulin sensitivity and } \\
\text { metabolic control in } \mathrm{T} 2 \mathrm{D} \text { patients with decreased } \\
\text { serum } \mathrm{Mg}^{2+} \text { levels }\end{array}$ \\
\hline Guerrero-Romero et al., 2004 [72] & $\mathrm{MgCl}_{2} 2.5 \mathrm{~g}$ daily for 3 months & $\begin{array}{l}\text { Oral } \mathrm{Mg}^{2+} \text { supplementation improves insulin } \\
\text { sensitivity in hypomagnesemic non-diabetic subjects }\end{array}$ \\
\hline Song et al., 2006 [73] & $360 \mathrm{mg} /$ day for 4-16 weeks & $\begin{array}{l}\text { Oral } \mathrm{Mg}^{2+} \text { supplementation reduces plasma fasting } \\
\text { glucose levels and increases HDL cholesterol in } \\
\text { patients with T2D }\end{array}$ \\
\hline Chacko et al., 2011 [74] & $500 \mathrm{mg} /$ day for 4 weeks & $\begin{array}{l}\mathrm{Mg}^{2+} \text { treatment significantly improves fasting } \\
\mathrm{C} \text {-peptide concentrations and fasting insulin } \\
\text { concentrations }\end{array}$ \\
\hline Mooren et al., 2011 [75] & $365 \mathrm{mg} /$ day for 6 months & $\begin{array}{l}\mathrm{Mg}^{2+} \text { supplementation resulted in a significant } \\
\text { improvement in fasting plasma glucose and insulin } \\
\text { sensitivity in normomagnesemic, overweight } \\
\text { non-diabetic subjects }\end{array}$ \\
\hline Solati et al., 2014 [76] & $300 \mathrm{mg} /$ day for 3 months & $\begin{array}{l}\text { Oral } \mathrm{Mg}^{2+} \text { supplementation has beneficial effects on } \\
\text { blood glucose, lipid profile, and blood pressure in } \\
\text { patients with T2D }\end{array}$ \\
\hline ELDerawi et al., 2019 [77] & $250 \mathrm{mg} /$ day for 3 months & $\begin{array}{l}\text { Oral } \mathrm{Mg}^{2+} \text { supplementation reduces IR and } \\
\text { improves glycemic control in T2D patients }\end{array}$ \\
\hline
\end{tabular}


These data indicate that special attention should be given to the risk groups, in particular individuals with MetS and T2D, in which serum $\mathrm{Mg}^{2+}$ levels should be monitored periodically. The current RDA for $\mathrm{Mg}^{2+}$ ranges from $80 \mathrm{mg}$ / day for children 1-3 years of age to $130 \mathrm{mg} /$ day for children 4-8 years of age. For older males, the RDA for $\mathrm{Mg}^{2+}$ ranges from as low as $240 \mathrm{mg} /$ day (range, 9-13 years of age) and increases to $420 \mathrm{mg} /$ day for males 31-70 years of age and older. For females, the RDA ranges from $240 \mathrm{mg} /$ day (9-13 years of age) to $360 \mathrm{mg} /$ day for females 14-18 years of age. The RDA for females 31-70 years of age and older is $320 \mathrm{mg} /$ day. Many nutritional experts feel the ideal intake for $\mathrm{Mg}^{2+}$ should be based on the body weight (e.g., 4-6 mg per $\mathrm{kg} /$ day) [57]. Organic bound $\mathrm{Mg}^{2+}$ salts, such as $\mathrm{Mg}^{2+}$ citrate, gluconate, orotate, or aspartate, are recommended in the treatment of $\mathrm{MgD}$ because of their high bioavailability [57,78]. A potential side effect from the use of $\mathrm{Mg}^{2+}$ salts may be the risk of developing hypoglycemia by increasing the intestinal absorption rate of SUs. Therefore, SUs should be given at least $1 \mathrm{~h}$ before $\mathrm{Mg}^{2+}$ intake [79].

Considering the numerous positive effects of $\mathrm{Mg}^{2+}$ on a number of mechanisms related to IR, consuming a healthy $\mathrm{Mg}^{2+}$-rich diet should be encouraged for individuals with MetS and T2D. There is consensus on the benefits of certain named dietary patterns, such as the Mediterranean diet and DASH (Dietary Approaches to Stop Hypertension) diet for prevention and management of T2D [80]. The Mediterranean diet is rich in $\mathrm{Mg}^{2+}$, dietary fiber, antioxidants, and polyphenolic compounds [81]. The DASH eating plan is an acceptable dietary pattern for people who have diabetes. In addition to promoting blood pressure control, this eating pattern has been shown to improve IR, hyperlipidemia, and even overweight/obesity [82]. The DASH diet contains larger amounts of $\mathrm{Mg}^{2+}, \mathrm{K}^{+}, \mathrm{Ca}^{2+}$, dietary fiber, and protein and smaller amounts of total and saturated fat and cholesterol than the typical diet [83].

\section{Conclusions}

Maintaining serum $\mathrm{Mg}^{2+}$ concentrations within the reference range is essential for normal insulin secretion and activity, as well as for the optimal functioning of many enzymes of glucose and energy metabolism. MgD may be associated with beta-cell dysfunction, IR, reduced glucose tolerance, and ultimately, clinical manifestations of T2D. Oral $\mathrm{Mg}^{2+}$ supplementation and appropriate dietary patterns improve insulin sensitivity and metabolic control in patients with T2D, suggesting that $\mathrm{Mg}^{2+}$ is an important factor in the etiology and management of this widespread socially significant disease.

Author Contributions: K.K. designed the review, interpreted the data, and wrote the manuscript. The author approved the final version of the manuscript.

Funding: This review was accomplished with the financial support from the Medical University-Pleven, Bulgaria.

Conflicts of Interest: The author declares no conflict of interest.

\section{References}

1. Roden, M.; Petersen, K.; Shulman, G. Insulin Resistance in Type 2 Diabetes. In Textbook of Diabetes, 5th ed.; Holt, R.I., Cockram, C., Flyvbjerg, A., Goldstein, B.J., Eds.; John Wiley \& Sons: New York City, NY, USA, 2017; pp. 174-186.

2. Xu, H.; Li, X.; Adams, H.; Kubena, K.; Guo, S. Etiology of Metabolic Syndrome and Dietary Intervention. Int. J. Mol. Sci. 2019, 20, 128. [CrossRef] [PubMed]

3. Salunkhe, V.A.; Veluthakal, R.; Kahn, S.E.; Thurmond, D.C. Novel approaches to restore beta cell function in prediabetes and type 2 diabetes. Diabetologia 2018, 61, 1895-1901. [CrossRef]

4. Singh, J.; Bidasee, K.R.; Adeghate, E.; Howarth, C.F.; D'Souza, A.; Singh, R.B. Left ventricle structural remodelling in prediabetes and overt type 2 diabetes mellitus in the Goto-Kakizaki rat. World Heart J. 2017, 9, $19-24$.

5. Kolte, D.; Vijayaraghavan, K.; Khera, S.; Sica, D.A.; Frishman, W.H. Role of magnesium in cardiovascular diseases. Cardiol. Rev. 2014, 22, 182-192. [CrossRef] [PubMed]

6. De Baaij, J.H.; Hoenderop, J.G.; Bindels, R.J. Magnesium in man: Implications for health and disease. Physiol. Rev. 2015, 95, 1-46. [CrossRef] 
7. Barbagallo, M.; Dominguez, L.J. Magnesium and type 2 diabetes. World J. Diabetes 2015, 6, 1152. [CrossRef]

8. Kostov, K.; Halacheva, L. Role of magnesium deficiency in promoting atherosclerosis, endothelial dysfunction, and arterial stiffening as risk factors for hypertension. Int. J. Mol. Sci. 2018, 19, 1724. [CrossRef] [PubMed]

9. Li, H.; Sun, S.; Chen, J.; Xu, G.; Wang, H.; Qian, Q. Genetics of magnesium disorders. Kidney Dis. 2017, 3, 85-97. [CrossRef] [PubMed]

10. McNair, P.; Christensen, M.S.; Christiansen, C.; Madsbad, S.; Transbøl, I.B. Renal hypomagnesaemia in human diabetes mellitus: Its relation to glucose homeostasis. Eur. J. Clin. Investig. 1982, 12, 81-85. [CrossRef]

11. Swaminathan, R. Magnesium metabolism and its disorders. Clin. Biochem. Rev. 2003, 24, 47-66.

12. Vormann, J. Magnesium and Kidney Health-More on the 'Forgotten Electrolyte'. Am. J. Nephrol. 2016, 44, 379-380. [CrossRef] [PubMed]

13. Florentin, M.; Elisaf, M.S. Proton pump inhibitor-induced hypomagnesemia: A new challenge. World J. Nephrol. 2012, 1, 151-154. [CrossRef] [PubMed]

14. Peters, K.E.; Chubb, S.P.; Davis, W.A.; Davis, T.M. The relationship between hypomagnesemia, metformin therapy and cardiovascular disease complicating type 2 diabetes: The Fremantle Diabetes Study. PLoS ONE 2013, 8, e74355. [CrossRef] [PubMed]

15. Barbagallo, M.; Dominguez, L.J. Magnesium metabolism in type 2 diabetes mellitus, metabolic syndrome and insulin resistance. Arch. Biochem. Biophys. 2007, 458, 40-47. [CrossRef] [PubMed]

16. Günther, $\mathrm{T}$. The biochemical function of $\mathrm{Mg}^{2+}$ in insulin secretion, insulin signal transduction and insulin resistance. Magnes. Res. 2010, 23, 5-18. [PubMed]

17. Barbagallo, M.; Dominguez, L.J. Magnesium and the cardiometabolic syndrome. Curr. Nutr. Rep. 2012, 1, 100-108. [CrossRef]

18. Geiger, H.; Wanner, C. Magnesium in disease. Clin. Kidney J. 2012, 5, i25-i38. [CrossRef]

19. Gommers, L.M.; Hoenderop, J.G.; Bindels, R.J.; de Baaij, J.H. Hypomagnesemia in type 2 diabetes: A vicious circle? Diabetes 2016, 65, 3-13. [CrossRef]

20. Tokarz, V.L.; MacDonald, P.E.; Klip, A. The cell biology of systemic insulin function. J. Cell Biol. 2018, 217, 2273-2289. [CrossRef]

21. Straub, S.G.; Sharp, G.W. Glucose-stimulated signaling pathways in biphasic insulin secretion. Diabetes Metab. Res. Rev. 2002, 18, 451-463. [CrossRef]

22. Nepton, S. Beta-Cell Function and Failure; InTech: London, UK, 2013; pp. 115-126.

23. Ashcroft, F.M.; Puljung, M.C.; Vedovato, N. Neonatal diabetes and the KATP channel: From mutation to therapy. Trends Endocrinol. Metab. 2017, 28, 377-387. [CrossRef]

24. Rosolova, H.; Mayer, O., Jr.; Reaven, G.M. Insulin-mediated glucose disposal is decreased in normal subjects with relatively low plasma magnesium concentrations. Metabolism 2000, 49, 418-420. [CrossRef]

25. Ward, C.W.; Lawrence, M.C. Ligand-induced activation of the insulin receptor: A multi-step process involving structural changes in both the ligand and the receptor. Bioessays 2009, 31, 422-434. [CrossRef]

26. Gutiérrez-Rodelo, C.; Roura-Guiberna, A.; Olivares-Reyes, J.A. Molecular mechanisms of insulin resistance: An update. Gaceta Médica de México 2017, 153, 214-228.

27. Chakraborty, C.; Agoramoorthy, G.; Hsu, M.J. Exploring the evolutionary relationship of insulin receptor substrate family using computational biology. PLoS ONE 2011, 6, e16580. [CrossRef]

28. Mardilovich, K.; Pankratz, S.L.; Shaw, L.M. Expression and function of the insulin receptor substrate proteins in cancer. J. Cell Commun. Signal. 2009, 7, 14. [CrossRef]

29. Lee, Y.; Fluckey, J.D.; Chakraborty, S.; Muthuchamy, M. Hyperglycemia-and hyperinsulinemia-induced insulin resistance causes alterations in cellular bioenergetics and activation of inflammatory signaling in lymphatic muscle. FASEB J. 2017, 31, 2744-2759. [CrossRef]

30. Shanik, M.H.; Xu, Y.; Škrha, J.; Dankner, R.; Zick, Y.; Roth, J. Insulin resistance and hyperinsulinemia: Is hyperinsulinemia the cart or the horse? Diabetes Care 2008, 31, S262-S268. [CrossRef]

31. Boura-Halfon, S.; Zick, Y. Phosphorylation of IRS proteins, insulin action, and insulin resistance. Am. J. Physiol. Endocrinol. Metab. 2009, 296, E581-E591. [CrossRef]

32. Boucher, J.; Kleinridders, A.; Kahn, C.R. Insulin receptor signaling in normal and insulin-resistant states. Cold Spring Harb. Perspect. Biol. 2014, 6, a009191. [CrossRef] 
33. Barbagallo, M.; Gupta, R.K.; Bardicef, O.; Bardicef, M.; Resnick, L.M. Altered ionic effects of insulin in hypertension: Role of basal ion levels in determining cellular responsiveness. J. Clin. Endocrinol. Metab. 1997, 82, 1761-1765. [CrossRef]

34. Chen, L.; Chen, R.; Wang, H.; Liang, F. Mechanisms linking inflammation to insulin resistance. Int. J. Endocrinol. 2015, 2015, 508409. [CrossRef]

35. Belin, R.J.; He, K. Magnesium physiology and pathogenic mechanisms that contribute to the development of the metabolic syndrome. Magnes. Res. 2007, 20, 107-129.

36. Rehman, K.; Akash, M.S.H. Mechanisms of inflammatory responses and development of insulin resistance: How are they interlinked? J. Biomed. Sci. 2016, 23, 87. [CrossRef]

37. Schlaepfer, D.D.; Hou, S.; Lim, S.T.; Tomar, A.; Yu, H.; Lim, Y.; Hanson, D.A.; Uryu, S.A.; Molina, J.; Mitra, S.K. Tumor necrosis factor- $\alpha$ stimulates focal adhesion kinase activity required for mitogen-activated kinase-associated interleukin 6 expression. J. Biol. Chem. 2007, 282, 17450-17459. [CrossRef]

38. Khodabandehloo, H.; Gorgani-Firuzjaee, S.; Panahi, G.; Meshkani, R. Molecular and cellular mechanisms linking inflammation to insulin resistance and $\beta$-cell dysfunction. Transl. Res. 2016, 167, 228-256. [CrossRef]

39. Guerrero-Romero, F.; Bermudez-Peña, C.; Rodríguez-Morán, M. Severe hypomagnesemia and low-grade inflammation in metabolic syndrome. Magnes. Res. 2011, 24, 45-53.

40. Nielsen, F.H. Magnesium, inflammation, and obesity in chronic disease. Nutr. Rev. 2010, 68, 333-340. [CrossRef]

41. King, D.E.; Mainous, A.G., III; Geesey, M.E.; Ellis, T. Magnesium intake and serum C-reactive protein levels in children. Magnes. Res. 2007, 20, 32-36.

42. King, D.E.; Mainous, A.G., III; Geesey, M.E.; Woolson, R.F. Dietary magnesium and C-reactive protein levels. J. Am. Coll. Nutr. 2005, 24, 166-171. [CrossRef]

43. Kim, D.J.; Xun, P.; Liu, K.; Loria, C.; Yokota, K.; Jacobs, D.R.; He, K. Magnesium intake in relation to systemic inflammation, insulin resistance, and the incidence of diabetes. Diabetes Care 2010, 33, 2604-2610. [CrossRef]

44. Pahlavani, M.; Ramalho, T.; Koboziev, I.; Monique, L.J.; Jayarathne, S.; Ramalingam, L.; Filgueiras, L.R.; Moustaid-Moussa, N. Adipose tissue inflammation in insulin resistance: Review of mechanisms mediating anti-inflammatory effects of omega-3 polyunsaturated fatty acids. J. Investig. Med. 2017, 65, 1021-1027. [CrossRef]

45. Chaudhary, D.P.; Boparai, R.K.; Sharma, R.; Bansal, D.D. Studies on the development of an insulin resistant rat model by chronic feeding of low magnesium high sucrose diet. Magnes. Res. 2004, 17, 293-300.

46. Voma, C.; Romani, A.M. Role of Magnesium in the Regulation of Hepatic Glucose Homeostasis; InTech: London, UK, 2014; pp. 95-111.

47. Beurel, E.; Grieco, S.F.; Jope, R.S. Glycogen synthase kinase-3 (GSK3): Regulation, actions, and diseases. Pharmacol. Ther. 2015, 148, 114-131. [CrossRef]

48. De Silva, B.; Gary, R.K. The GSK3 kinase inhibitor lithium produces unexpected hyperphosphorylation of $\beta$-catenin, a GSK3 substrate, in human glioblastoma cells. Biol. Open 2018, 7, bio030874.

49. Medina, M.; Wandosell, F. Deconstructing GSK-3: The fine regulation of its activity. Int. J. Alzheimers Dis. 2011, 2011, 479249. [CrossRef]

50. Pilchova, I.; Klacanova, K.; Tatarkova, Z.; Kaplan, P.; Racay, P. The Involvement of $\mathrm{Mg}^{2+}$ in Regulation of Cellular and Mitochondrial Functions. Oxid. Med. Cell. Longev. 2017, 2017, 1-8. [CrossRef]

51. Garfinkel, L.; Garfinkel, D. Magnesium regulation of the glycolytic pathway and the enzymes involved. Magnesium 1985, 4, 60-72.

52. Ferrè, S.; de Baaij, J.H.; Ferreira, P.; Germann, R.; de Klerk, J.B.; Lavrijsen, M.; van Zeeland, F.; Venselaar, H.; Kluijtmans, L.A.; Hoenderop, J.G.; et al. Mutations in PCBD1 cause hypomagnesemia and renal magnesium wasting. J. Am. Soc. Nephrol. 2014, 25, 574-586. [CrossRef]

53. Adalat, S.; Woolf, A.S.; Johnstone, K.A.; Wirsing, A.; Harries, L.W.; Long, D.A.; Hennekam, R.C.; Ledermann, S.E.; Rees, L.; van't Hoff, W.; et al. HNF1B mutations associate with hypomagnesemia and renal magnesium wasting. J. Am. Soc. Nephrol. 2009, 20, 1123-1131. [CrossRef]

54. Chan, K.H.K.; Chacko, S.A.; Song, Y.; Cho, M.; Eaton, C.B.; Wu, W.C.H.; Liu, S. Genetic Variations in Magnesium-Related Ion Channels May Affect Diabetes Risk among African American and Hispanic American Women 1-3. J. Nutr. 2015, 145, 418-424. [CrossRef]

55. De Baaij, J.H.; Hoenderop, J.G.; Bindels, R.J. Regulation of magnesium balance: Lessons learned from human genetic disease. Clin. Kidney J. 2012, 5, i15-i24. [CrossRef] 
56. Altura, B.M.; Li, W.; Zhang, A.; Zheng, T.; Shah, N.C. Sudden cardiac death in infants, children and young adults: Possible roles of dietary magnesium intake and generation of platelet-activating factor in coronary arteries. J. Heart Health 2016, 2, 1-5.

57. Gröber, U.; Schmidt, J.; Kisters, K. Magnesium in prevention and therapy. Nutrients 2015, 7, 8199-8226. [CrossRef]

58. Kass, L.; Sullivan, K.R. Low Dietary Magnesium Intake and Hypertension. World J. Cardiovasc. Dis. 2016, 6, 447-457. [CrossRef]

59. Galan, P.; Preziosi, P.; Durlach, V.; Valeix, P.; Ribas, L.; Bouzid, D.; Favier, A.; Hercberg, S. Dietary magnesium intake in a French adult population. Magnes. Res. 1997, 10, 321-328.

60. Ismail, A.A.; Ismail, N.A. Magnesium: A mineral essential for health yet generally underestimated or even ignored. J. Nutr. Food Sci. 2016, 6, 523. [CrossRef]

61. Standing Committee on the Scientific Evaluation of Dietary Reference Intakes; Food and Nutrition Board; Institute of Medicine (IOM). Dietary Reference Intakes for Calcium, Phosphorus, Magnesium, Vitamin D, and Fluoride; National Academies Press: Washington, DC, USA, 1997.

62. Rosanoff, A. The high heart health value of drinking-water magnesium. Med. Hypotheses 2013, 81, $1063-1065$. [CrossRef]

63. Lopez-Ridaura, R.; Willett, W.C.; Rimm, E.B.; Liu, S.; Stampfer, M.J.; Manson, J.E.; Hu, F.B. Magnesium intake and risk of type 2 diabetes in men and women. Diabetes Care 2004, 27, 134-140. [CrossRef]

64. Van Dam, R.M.; Hu, F.B.; Rosenberg, L.; Krishnan, S.; Palmer, J.R. Dietary calcium and magnesium, major food sources, and risk of type 2 diabetes in US black women. Diabetes Care 2006, 29, 2238-2243. [CrossRef]

65. Kausalya, P.J.; Amasheh, S.; Günzel, D.; Wurps, H.; Müller, D.; Fromm, M.; Hunziker, W. Disease-associated mutations affect intracellular traffic and paracellular $\mathrm{Mg}^{2+}$ transport function of Claudin-16. J. Clin. Investig. 2006, 116, 878-891. [CrossRef]

66. Raman, V.; Cohen, R.A. Hypomagnesemia in a patient with an eating disorder. Am. J. Kidney Dis. 2018, 71, A12-A14. [CrossRef]

67. Barbagallo, M.; Dominguez, L.J. Magnesium and type 2 diabetes: An Update. Int. J. Diabetes Clin. Res. 2015, 2, 019. [CrossRef]

68. Schuchardt, J.P.; Hahn, A. Intestinal absorption and factors influencing bioavailability of magnesium-An update. Curr. Nutr. Food Sci. 2017, 13, 260-278. [CrossRef]

69. Costello, R.; Wallace, T.C.; Rosanoff, A. Magnesium. Adv. Nutr. 2016, 7, 199-201. [CrossRef]

70. Dimke, H.; Hoenderop, J.G.; Bindels, R.J. Molecular basis of epithelial $\mathrm{Ca}^{2+}$ and $\mathrm{Mg}^{2+}$ transport: Insights from the TRP channel family. J. Physiol. 2011, 589, 1535-1542. [CrossRef]

71. Rodríguez-Morán, M.; Guerrero-Romero, F. Oral magnesium supplementation improves insulin sensitivity and metabolic control in type 2 diabetic subjects: A randomized double-blind controlled trial. Diabetes Care 2003, 26, 1147-1152. [CrossRef]

72. Guerrero-Romero, F.; Tamez-Perez, H.E.; González-González, G.E.; Salinas-Martinez, A.M.; Montes-Villarreal, J.; Trevino-Ortiz, J.H.; Rodriguez-Moran, M. Oral magnesium supplementation improves insulin sensitivity in non-diabetic subjects with insulin resistance. A double-blind placebo-controlled randomized trial. Diabetes Metab. 2004, 30, 253-258. [CrossRef]

73. Song, Y.; He, K.; Levitan, E.B.; Manson, J.E.; Liu, S. Effects of oral magnesium supplementation on glycaemic control in Type 2 diabetes: A meta-analysis of randomized double-blind controlled trials. Diabet. Med. 2006, 23, 1050-1056. [CrossRef]

74. Chacko, S.A.; Sul, J.; Song, Y.; Li, X.; LeBlanc, J.; You, Y.; Butch, A.; Liu, S. Magnesium supplementation, metabolic and inflammatory markers, and global genomic and proteomic profiling: A randomized, double-blind, controlled, crossover trial in overweight individuals. Am. J. Clin. Nutr. 2011, 93, 463-473. [CrossRef]

75. Mooren, F.C.; Krüger, K.; Völker, K.; Golf, S.W.; Wadepuhl, M.; Kraus, A. Oral magnesium supplementation reduces insulin resistance in non-diabetic subjects-A double-blind, placebo-controlled, randomized trial. Diabetes Obes. Metab. 2011, 13, 281-284. [CrossRef]

76. Solati, M.; Ouspid, E.; Hosseini, S.; Soltani, N.; Keshavarz, M.; Dehghani, M. Oral magnesium supplementation in type II diabetic patients. Med. J. Islam. Repub. Iran 2014, 28, 67.

77. ELDerawi, W.; Naser, I.; Taleb, M.; Abutair, A. The Effects of Oral Magnesium Supplementation on Glycemic Response among Type 2 Diabetes Patients. Nutrients 2019, 11, 44. [CrossRef] 
78. Rosique-Esteban, N.; Guasch-Ferré, M.; Hernández-Alonso, P.; Salas-Salvadó, J. Dietary Magnesium and Cardiovascular Disease: A Review with Emphasis in Epidemiological Studies. Nutrients 2018, 10, 168. [CrossRef]

79. May, M.; Schindler, C. Clinically and pharmacologically relevant interactions of antidiabetic drugs. Ther. Adv. Endocrinol. Metab. 2016, 7, 69-83. [CrossRef]

80. Forouhi, N.G.; Misra, A.; Mohan, V.; Taylor, R.; Yancy, W. Dietary and nutritional approaches for prevention and management of type 2 diabetes. Br. Med. J. 2018, 361, k2234. [CrossRef]

81. Park, Y.M.; Steck, S.E.; Fung, T.T.; Zhang, J.; Hazlett, L.J.; Han, K.; Lee, S.H.; Kwon, H.S.; Merchant, A.T. Mediterranean diet, Dietary Approaches to Stop Hypertension (DASH) style diet, and metabolic health in US adults. Clin. Nutr. 2017, 36, 1301-1309. [CrossRef]

82. Campbell, A.P. DASH eating plan: An eating pattern for diabetes management. Diabetes Spectr. 2017, 30, 76-81. [CrossRef]

83. Sacks, F.M.; Svetkey, L.P.; Vollmer, W.M.; Appel, L.J.; Bray, G.A.; Harsha, D.; Obarzanek, E.; Conlin, P.R.; Miller, E.R., 3rd; Simons-Morton, D.G.; et al. Effects on blood pressure of reduced dietary sodium and the Dietary Approaches to Stop Hypertension (DASH) diet. N. Engl. J. Med. 2001, 344, 3-10. [CrossRef]

(C) 2019 by the author. Licensee MDPI, Basel, Switzerland. This article is an open access article distributed under the terms and conditions of the Creative Commons Attribution (CC BY) license (http:/ / creativecommons.org/licenses/by/4.0/). 